University at Albany, State University of New York

Scholars Archive

Educational \& Counseling Psychology Faculty

Scholarship

Educational \& Counseling Psychology

2016

\title{
Applications of Peer Assessment and Self-Assessment in Music
}

\author{
Christopher Valle \\ Excelsior College \\ Heidi Andrade \\ University at Albany, State University of New York, handrade@albany.edu \\ Maria Palma \\ New York City Department of Education \\ Joanna Hefferen \\ Arts Connection, New York City
}

Follow this and additional works at: https://scholarsarchive.library.albany.edu/edpsych_fac_scholar

Part of the Educational Assessment, Evaluation, and Research Commons

\section{Recommended Citation}

Valle, Christopher; Andrade, Heidi; Palma, Maria; and Hefferen, Joanna, "Applications of Peer Assessment and Self-Assessment in Music" (2016). Educational \& Counseling Psychology Faculty Scholarship. 11. https://scholarsarchive.library.albany.edu/edpsych_fac_scholar/11

This Article is brought to you for free and open access by the Educational \& Counseling Psychology at Scholars Archive. It has been accepted for inclusion in Educational \& Counseling Psychology Faculty Scholarship by an authorized administrator of Scholars Archive. For more information, please contact scholarsarchive@albany.edu. 


\title{
Applications of Peer and Self-Assessment in Music
}

\author{
Christopher Valle, Heidi Andrade, Maria Palma and Joanna Hefferen
}

Music teachers strive to help students become independent musicians who are capable of critiquing their own learning, work, and performance, and make improvements based on feedback. Classroom assessment strategies that engage students in providing feedback to themselves and each other can create a shared responsibility for listening, critiquing, and revising, and can help students assume greater independence in and control over their learning. Educators have tested a number of formative classroom-based assessment strategies that include students as a key source of feedback throughout the learning process (Andrade \& Cizek, 2010). While several music scholars have offered guidelines for drawing on students as sources of feedback during assessment (Burrack, 2011; Goolsby, 1999; Hale \& Green, 2009), there exist few models that provide explicit guidance on how to engage students in a formative music assessment process, and even fewer exemplars of appropriate tools that elicit the kind of information that leads to higher levels of learning and better instructional decisions. In this article, we share the work of several classroom music teachers who have designed cutting-edge formative assessment techniques with potential to elevate each student's engagement and learning in music. The article provides a brief account of their work, and shares several examples of assessment centered on promoting student learning in music.

Recent discussions of formative assessment in music have focused on the potential learning benefits of rubrics, self-reflection, and self- and peer assessment, as well as practical strategies for promoting learning through assessment (Crochet \& Green, 2012; DeLuca \& Bolden, 2014; Hale \& Green, 2009; Parkes, 2010; Scott, 2012). Hale and Green (2009) argued 
that self-assessment is a key principle for good music assessment. They suggested that teachers facilitate self- and peer assessment with guided questioning and engage students in rubricreferenced assessment of their own recorded performances. Like Hale and Green, Parkes (2010) stressed the need for descriptive and clear rubric criteria, suggesting that assessment that references detailed criteria yields targeted and specific feedback on areas in need of improvement. Parkes' brass performance rubric is an excellent example of the level of detail needed to distinguish between strong and weak performances. As noted by Wesolowski (2014), student-centered assessment can also yield thorough and accurate documentation of learning progress and achievement, which not only helps teachers monitor student learning and identify areas in need of improvement, but also fulfills the need for greater accountability. Like many music educators and scholars, Sinsabaugh (2015) and DeLuca and Bolden (2014) regard selfassessment as an essential skill for musicians and argue that learning how to self-assess ultimately fosters independent learning.

The Artful Learning Communities (ALC) professional development project described in this article was supported by a grant from the U.S. Department of Education. The goals of the project were to 1) strengthen the capacity of elementary and middle school arts teachers to assess standards-based learning in the arts, 2) promote increased student achievement in the arts through ongoing classroom assessment, and 3) develop the ability of teachers to define, systematize and communicate their assessment strategies and tools to local and national audiences. We worked with 96 visual art, music, dance, and theater teachers and their 48,000 students in grades 3 through 8 at high-poverty schools in New York City. The teachers engaged in action research focused on collaborative inquiry into student achievement in the arts in 
professional learning communities that brought them together across schools. In this article, we focus on work of the music teachers.

The music teachers involved in the ALC project were already familiar with summative assessment practices in music such as the use of adjudication forms and similar summativefocused instruments designed to rate music performances (Latimer, 2007). To emphasize the summative versus formative distinction, that is assessment of learning rather than for learning (Stiggins, 2006), theory and research on formative assessment strategies were presented in professional development sessions that stressed the ways in which ongoing feedback from both teacher and students can deepen students' understanding of important concepts and skills (Andrade, Du, \& Mycek, 2010). The teachers were shown evidence that learning could improve when students: 1) understand learning goals and performance targets, 2) recognize gaps in their skills and understanding in relation to the goals and targets, and 3) are provided strategies for closing gaps through relearning and revision (Sadler, 1989; Black \& Wiliam, 1998).

Self- and peer assessment were two processes of formative assessment that teachers were encouraged to use in their classrooms. In music, self-assessment is a key element of effective independent practice (McPherson \& Renwick, 2011). During self-assessment, students critique their work according to explicitly stated expectations, usually in the form of goals or criteria, and then engage in the revision process to improve their work. Self-assessment serves the purpose of improving the quality of first attempts at a piece of work so that the finished product or performance meets or exceeds expectations. Given this purpose, self-assessment is not selfevaluation, which is assigning a grade to one's own work. Rather, self-assessment is meant to give students an opportunity to take control over their learning by having them assess gaps in their own understanding and skills, and then use what they learn about their strengths and 
weaknesses as feedback for closing those gaps. According to Andrade (2010), there are three key steps to self-assessment: 1) articulating expectations, 2) critiquing work in terms of those expectations, and 3) revising. As will be seen in the case studies below, the teachers in the ALC project typically articulate expectations by sharing or co-creating a rubric or checklist with students. When students have had time to work on their performances, step two involves teacher, peer, and/or self-generated feedback according to the rubric or checklist. Step three is crucial: Students must have opportunities to revise and improve their performances, or step two is pointless.

Peers are also a powerful source of feedback. Students can give each other feedback using the same procedure outlined above: 1) articulating expectations, perhaps using a rubric or checklist, 2) teacher, peer, and/or self-feedback, and 3) revision and improvement (Andrade, 2010). For peer feedback to be useful, however, students need to deliver it using a constructive process. The constructive critique protocol that the music teachers were encouraged to use is called the Ladder of Feedback (Perkins, 2003). This protocol has four steps of equal importance: 1) the deliverer of the feedback first asks questions of clarification about the other student's work, then 2) identifies strengths and other aspects of the work that are of value, 3) raises concerns about the work, and finally 4) offers suggestions for ways in which the other student can improve his or her work. It is crucial that feedback focuses on the task rather than the individual, and that it includes specific suggestions for how to improve the quality of one's work and performance.

In conceptualizing assessment as a moment of learning (Zessoules \& Gardner, 1991), the music teachers realized that self- and peer assessment are authentic artistic processes that are apposite to music making and important to any endeavor that involves rehearsal and redoing: 
setting goals, assessing work, and revising. Realizing the power of formative assessment, the teachers focused their assessment efforts on orienting students towards specific learning goals by articulating clear expectations aligned with the standards outlined by the New York City Blueprint for Teaching and Learning in Music. The music teachers explained and modeled how to engage in constructive peer and self-assessment, and supported students in revising the quality of their work to meet the expectations set forth by the targeted learning goals and performance expectations.

The remainder of this article introduces several approaches to assessment used in music classes at the elementary grade levels. The work of three music teachers is described in three sections. Within each section, the teacher's background and her work is described first, followed by a discussion of the assessment tools she used. Following this is a brief reflection by the teacher and a discussion of the formative assessment practices applied in her unit.

\section{Ms. Michelle Turner, $\mathbf{1}^{\text {st }}$ Grade Keyboard Unit}

Ms. Michelle Turner is a kindergarten through fifth grade teacher at Public School 36 in the Bronx, where she has taught for 16 years. Shortly after starting at P.S. 36, she was awarded a VH1 grant to establish a keyboard lab and engage students in the Music and the Brain curriculum, a learning sequence intended for primary age learners.

Ms. Turner designed a first grade keyboard unit with goals focused on developing students' skill in performing with two hands and fluency in pitch and rhythm. Noticing that students generally did not maintain a consistent tempo when playing keyboard music, Ms. Turner also set a goal of “developing an internal clock," which she referred to as "the inside ‘tick-tock' that should stay the same to the end of the piece.” 
On the first day of the unit, Ms. Turner posed the following question to students: "What do I have to do at the keyboard to make what is on the page sound like the song we sing?” This question initiated a dialogue about what good keyboard playing looks like and how it soundsthe learning goals and performance expectations for the unit. In the next class session, Ms. Turner presented the checklist shown in Figure 1, which captured students' descriptions of the three learning goals for this unit: pitch, beat, and rhythm. The checklist was discussed with the class and posted around the classroom for reference throughout the unit.

Ms. Turner asked students to assess several musical examples in terms of pitch and rhythm to help them become familiar with the criteria and checklist. Students were then asked to self-assess their keyboard playing using the pitch and rhythm criteria listed on the checklist. Students used the reflection sheet shown in Figure 2 to document the criterion they felt needed the most work. This reflection tool also asked students to indicate why they thought that particular criterion needed work. For example, one first grader wrote "did not use the correct fingering," referring to the "I use the correct fingers" description under the "Pitch" criterion.

Ms. Turner's reflections on the unit suggested that the checklist was helpful not only in providing information to adjust instruction based on students' learning needs, but also in facilitating students' keyboard practice. At the beginning of the unit, she reviewed students' checklists and found that some students remained perplexed about the distinction between pitch and rhythm. To remedy this, she retaught these two concepts and revised the checklist descriptors with her students. When reviewing students' reflections, Ms. Turner found that they frequently stopped during a performance when they encountered a difficult rhythm or to reposition their hands in order to sound the correct pitch. Based on students' reflections, Ms. 
Turner chose to focus initially on pitch and rhythm. Ms. Turner told students that as they fulfilled the pitch and rhythm criteria, they would be prepared to achieve the beat criterion.

Because the checklist described good keyboard playing, students knew what to do to improve, reducing the amount of time spent on explaining or addressing problems as a group. Students did quick checklist self-assessments at the piano, which not only kept them playing but also helped them focus their practicing efforts on mastering specific aspects of their performance - pitch, beat, and rhythm. Students immediately resumed practicing after assessing themselves and considering what and how to revise, based on their self-assessments. The checklist and reflection tool were also helpful to Ms. Turner. Information from the checklist and reflection provided her with valuable insight into students' understandings and misconceptions in terms of pitch, beat, and rhythm, which she then used to adjust her instruction.

To her delight, Ms. Turner found that in general, students made gains in their practice skills and performance. Students were paying close attention to their performance when practicing, instead of mindlessly playing through the piece. Ms. Turner stated, "I observed an increasing number of students be more self-directed as to what to do next rather than to just play through a piece once.” With regard to improvements in student learning, Ms. Turner reported that at the end of the unit, students had a better feel for the "steady tick-tock beat" of music and were beginning to understand that keyboard music should flow and sound "like the way we sing it.” One of her students indicated that she understood that revision leads to mastery, stating, "Sometimes it takes more than three times to get a song right."

Ms. Turner's keyboard unit is an excellent example of strong implementation of the formative assessment model advocated by the ALC project. The process implemented by Ms. Turner exhibits each of the three key aspects of assessment for learning: understanding learning 
goals and expectations, identifying learning gaps in relation to goals and expectations, and closing learning gaps through revision based on feedback. At the start of the unit, learning targets were clearly articulated through co-creation of the checklist assessment tool. Involving students in the creation of criteria was intended to ensure that all students understand the learning goals and performance targets. With the aid of the checklist, students engaged in constructive formative assessment. They used the checklist descriptions of what constituted strong pitch, beat, and rhythm performance to generate feedback that indicated areas in need of improvement as well as ways to elevate the quality of their performance to meet the criteria. The feedback that students generated provided specific strategies and directions for revising their performance to meet the criteria and achieve the learning goals of the unit.

\section{Ms. Meghan Phadke, $3^{\text {rd }}$ Grade Recorder}

Ms. Meghan Phadke is a Kodály trained prekindergarten through $5^{\text {th }}$ grade teacher at Positive Successful Innovative School 111 in Manhattan. Ms. Phadke teaches general music with prekindergarten through $3^{\text {rd }}$ grade students, and small and large ensembles with grades 4 and 5. She also directs two bands, three guitar groups, and two choirs. Her $3^{\text {rd }}$ grade students engage in a "link-up" Carnegie hall recorder program where Ms. Phadke supplements instruction with folk songs and traditional repertoire to scaffold students' recorder learning. Ms. Phadke introduces students to recorder playing to set a foundation for working on instruments and to prepare them for participating in an ensemble in the 4th grade.

Prior to developing assessment tools, Ms. Phadke’s third grade students had about six weeks of experience learning basic recorder technique and rehearsing simple songs. Over the course of six class sessions, Ms. Phadke worked collaboratively with her students to identify specific areas in need of improvement in their recorder playing and to start developing practice 
strategies. The main goal of the unit was to have students begin to assume greater control and ownership over their recorder learning and practicing so they could be more self-directed and learn at their own pace. Throughout the unit, Ms. Phadke asked students, "How do we learn a song? What are the things we need to do as musicians? What are the steps?”

In the first class session, Ms. Phadke co-created criteria by asking students to consider what needs to be done to learn a new song on the recorder. Through this dialogue, Ms. Phadke guided students in determining the characteristics that represent good recorder practice strategies. Ms. Phadke organized this information, consolidated it into 11 steps, and created a Recorder Practice Checklist for use in following class sessions and for practice at home (see Figure 3). After the checklist was finalized, students used it to begin learning an arrangement of Beethoven’s “Ode to Joy.” Ms. Phadke carefully scaffolded students’ use of this checklist to help clarify points of confusion and to develop students’ self-assessment skills.

A similar process was used in subsequent class sessions to co-create criteria for improving one's sound when performing on the recorder. Although Ms. Phadke noticed improvements in students’ learning and performance, she found that many could not pass a playing test even after following every step on the practice checklist. Ms. Phadke reasoned that students’ recorder performance could improve if they knew the characteristics of a good performance and what problems they might encounter when performing. Ms. Phadke had students think of specific strategies and "mental checks” for each criterion that would help them focus their thinking and improve particular aspects of their playing. Ms. Phadke took these criteria and strategies and created self- and peer assessment tools. The rest of the class sessions were spent scaffolding students' use of these checklists. 
The two checklists in Figure 4 show the criteria for the sound of a song on the recorder when it is played well and the specific strategies students can use to improve their playing. Students used the checklists by listening to their playing and assessing it using the targeted "Skill” criteria. If students determined that their playing did not meet the expectation set by those criteria, then they referred to the “How do I fix it?” category to get a specific strategy on what they could do to improve. The same procedure was followed when giving feedback to a peer. In this way, feedback according to this checklist was always targeted, specific, and focused on improvement. Following both self- and peer assessment, students used the feedback to make revisions to their performance.

When reflecting on the unit, Ms. Phadke felt that her assessment tools were useful in helping students become more in control over their learning and served as a good source of evidence of student learning. Like Ms. Turner, Ms. Phadke found that her students were more independent when using the checklists and could work through each step at their own pace. Because the self- and peer assessments described clear performance expectations and provided strategies for how to fix problem areas, students were able to troubleshoot and resolve problems without seeking help. Ms. Phadke was pleased to see that students used the checklist strategies to help better each other's performances - they even celebrated small victories when checking off each checklist criterion.

For Ms. Phadke, students’ newly found independence meant that she could float around the music room and attend to individual students who needed one-on-one assistance. Ms. Phadke found that the checklists were not only a useful learning tool for her students, but also served as a great accountability tool for her as a teacher. Ms. Phadke was thrilled to have evidence and documentation of student progress and learning: "I love having written data/evidence about how 
[my students] are doing.” Watching students use the tools provided valuable insight into students' progress in learning to play the recorder: "The interesting thing for me - watching them use the checklist - was that they were working at their own pace, so I could see where they were getting stalled, where they needed help, where the holes in their skills were... it was so illuminating!"

Ms. Phadke's recorder unit is similar to Ms. Turner's in that it also demonstrates excellent use of articulating learning goals, generating feedback in relation to those goals, and revision based on feedback. This unit included an additional assessment feature: a list of revision strategies for each criterion on the checklist. The checklists co-created by Ms. Phadke and her students represented the characteristics and strategies for masterful performance, and served to articulate clear and specific expectations for learning and improvement. The checklists enabled students to identify areas of their own or a peer's performance in need of improvement and helped them deliver feedback to achieve the criteria articulated by the checklist. In addition, the "How do I fix it?” strategies - checking posture, clapping the rhythm, slowing down the tempo, etc. - provided immediate, actionable next steps to which students' referred when generating feedback and that they immediately used when revising their performance. As a whole, the formative assessment process that Ms. Phadke implemented in this unit was designed to help students achieve the primary learning goal of the unit: to construct a strong repertoire of practice strategies.

\section{Ms. Maria Comba, $4^{\text {th }}$ Grade Melody Unit}

Ms. Maria Comba is a 10 year veteran of the New York City Public School system and is currently serving as an elementary school music teacher at P.S. 247 in Brooklyn. Ms. Comba designed and implemented a unit on melody to train students to hear melody lines and to develop 
skills in notating simple melodies. This unit focused on ear training and melodic dictation, and was taught in two class sessions. Students were tasked with listening carefully to a melody in order to draw the shape, or contour, of the melody line. The concept here was that the organization of sounds that make up a melody can be represented visually by a line that is placed within some defined space (a music staff) and shaped across time (following the raising and lowering of pitches). The specific learning targets for this lesson were to 1) understand the concept of melody, 2) understand and be able to distinguish between the melody line and the accompaniment, 3) understand how melody is developed, and 4) use vocabulary appropriately when speaking about melody.

Several strategies were used at the very beginning of instruction to prepare students for listening to a melody. Ms. Comba began by activating students’ prior knowledge in two ways. First, students warmed-up their voices using solfège, Curwen/Kodály hand signs, and tonal patterns from Gordon’s Music Learning Theory (Gordon, 2012). This warm up set the stage for thinking about the relationship between pitches. To get students thinking about melodic lines, Ms. Comba had students draw from their experiences in visual arts classes to discuss different types of lines and the functions of lines. Ms. Comba led this conversation to a discussion on horizontal lines and how melody can be thought of as a line varying in shape, or simply a contour line. Students then practiced drawing different types of lines on white boards and used a basic set of vocabulary to describe them: straight, bumpy, wiggling, sharp, etc. Later, traditional vocabulary related to melody was reviewed and used to describe pitch relationships and movement.

To demonstrate the connection between lines and melody, Ms. Comba sang four different lines using a neutral “eu” sound. Ms. Comba asked students to use their music vocabulary to 
describe what was happening to their voices as they experimented with singing lines that they drew. Ms. Comba then introduced the term "contour" and related it to the shape that melodies assume in music. Four volunteers were asked to draw four different lines on the SmartBoard and indicate with a marker those points on each line where the pitch relationships ascend, descend, or remain the same. Ms. Comba used those four line contours to introduce the term melody. To reinforce the melody line concept, Ms. Comba played several excerpts on the piano, first with accompaniment and then with the melody alone. Students were then tasked with identifying, singing, and drawing the contour of each melody line Ms. Comba performed. Ms. Comba then gave students a melody checklist (shown in Figure 5), modeled how to use it, reviewed the vocabulary previously used, and asked students to use the checklist to draw and assess contours from different musical excerpts.

At the end of the first lesson, Ms. Comba gave students a melody rubric (shown in Figure 6) for use throughout the remainder of the unit. To transition students from the checklist to the rubric, Ms. Comba first provided a brief lesson on notating a melody based on the gaps in student learning revealed by information from students' melody checklists. The lesson involved reviewing the names of the notes on the staff and asking students to recognize the direction pitches move relative to a given starting pitch. Relevant vocabulary was reviewed as well, including ascending, descending, stepwise, skips, etc. After the lesson, students were asked to use the rubric to assess their work as they notated and sang the melody of musical excerpt. When using the rubrics, students were asked to articulate their goal or "next step" and what actions could be taken to improve.

A powerful feature of the melody rubric is the "now I'm working on" phrases. These brief indictors of next steps give students explicit instructions on what they need to do to elevate 
their work to the "I’ve GOT it!" level. The guidance provided by the "now I’m working on" phrases are important because students can often tell that their playing can improve but they usually do not know how to isolate weaknesses, and struggle to identify specific areas in need of improvement. Ms. Comba’s rubric not only clearly describes strong and weak work, but also provides goals for students' work and describes specific strategies for meeting those goals. Having explicitly stated goals and next step procedures on the rubric gives students immediate and appropriate strategies for improving the quality of their work and also helps to develop goalsetting, which is an essential first step in regulating one's learning.

Ms. Comba's reflections indicated that the checklists and rubrics improved students' understanding and performance of melody. Ms. Comba acknowledged that, while a great deal of time was spent on scaffolding and modelling, the effort was more than worth it - throughout the entire learning process, students knew what was expected of them and what to do next to improve. In this way, instruction was tailored to each students' learning needs. Ms. Comba found that students' responses from the checklists and rubrics provided useful information for tailoring her own instruction and helped her better organize her lessons. Ms. Comba was very pleased that students not only improved their ability to draw the general shape of a melodic line, notate the pitches of a melody on the staff, and sing a melody, but were also able to describe their level of progress using appropriate music vocabulary. Ms. Comba stated that "since a strong emphasis was placed on explaining their goals, the next step, students were constantly tasked with using music vocabulary and reflecting on their own work based upon models and exemplars.”

Ms. Comba's melody unit demonstrates not only how to use formative assessment to teach complex concepts like melody, but also the benefits of using a rubric as a tool for formative assessment. After using the Melody Checklist in similar ways as Ms. Turner and Ms. 
Phadke, Ms. Comba transitioned students to the rubric by re-teaching and reinforcing vocabulary related to melody, in order to ensure that students understood the expectations outlined by the rubric prior to using it for assessment. Ms. Comba’s transition to a rubric is an example of expanding each checklist criterion to include varying levels of quality. The additional descriptions provided students with a continuum for assessing each melody criterion, and allowed them to hone in on their progress when learning. Like Ms. Phadke's checklist, the three right-most levels of the Melody Rubric recommend strategies that students can use when revising their performance in the form of "Now I'm working on" phrases. When working on singing a melody, for example, students determine whether they match both the pitches and the direction of a melodic line and can practice singing each individual pitch if they do not match. Ms. Comba's rubric enabled students, regardless of where they were in the learning process, to generate feedback that was specific and immediately actionable.

\section{Conclusion}

Research is starting to emerge that sheds light on the power of formative assessment practices in music education. In two recent studies of formative assessment in the arts (Andrade et al., 2014; Mastrorilli, 2014), music students had significantly higher music achievement when their teacher used formative assessment practices similar to those described in this article: clarifying expectations and performance targets, revealing gaps in skills and understanding in relation to expectations and targets, and closing gaps through revision. Teachers in the Artful Learning Communities project echoed the findings from research. Reflections from the three music teachers highlighted in this article, as well as comments from other ALC participants, indicated that as students became more independent in their learning, they were free to assist students most in need. When asked to summarize the positive benefits of using formative 
assessment in their classrooms, each teacher offered a similar sentiment: Through peer and selfassessment, students not only made great strides in their learning and performance, but also became more self-directed and self-sufficient.

Author Note: The Artful Learning Communities project is a partnership between the New York City Department of Education (NYCDOE) and ArtsConnection, a U.S. Department of Education-recognized model arts education organization. The contents of this article were developed under a grant from the U.S. Department of Education. The contents do not necessarily represent the policy of the NYCDOE, and endorsement by the Federal Government should not be assumed. 


\section{References}

Andrade, Heidi. L. 2010. "Students as the Definitive Source of Formative Assessment: Academic Self-Assessment and the Self-regulation of Learning.” In Handbook of Formative Assessment, edited by Heidi L. Andrade and Gregory. J. Cizek, 90-105. New York: Routledge.

Andrade, Heidi. L., Fei Chen, Christopher Valle, Angela Lui, and Hirah Mir. 2014. “An Empirical Investigation of Criteria-Referenced Formative Assessment in the Arts.” Paper presentation at the annual meeting for the American Educational Research Association, Philadelphia, PA, April 3-7.

Andrade, Heidi L. and Gregory J. Cizek. 2010. Handbook of Formative Assessment. New York: Routledge.

Andrade, Heidi, Ying Du, and Kristina Mycek. 2010. "Rubric-referenced Self-assessment and Middle School Students' Writing.” Assessment in Education: Principles, Policy, \& Practice 17:199-214.

Black, Paul and Dylan Wiliam. 1998. "Inside the Black Box: Raising Standards through Classroom Assessment.” Phi Delta Kappan 80:139-148.

Burrack, Frederick. 2011. "Enhanced Assessment in Instrumental Programs.” Music Educator Journal 88: 27-32.

Crochet, Lorrie S. and Susan K. Green. 2012. "Examining Progress Across Time with Practical Assessments in Ensemble Settings.” Music Educators Journal 98: 49-54.

DeLuca, Christopher and Benjamin Bolden. 2014. "Music Performance Assessment: Exploring Three Approaches for Quality Rubric Construction.” Music Educators Journal 101:7076.

Goolsby, Thomas W. 1999. “Assessment in Instrumental Music.” Music Educators Journal 86:31-35.

Gordon, Edwin. 2012. Learning Sequences in Music: A Contemporary Music Learning Theory. Chicago, IL: GIA Publications, Inc.

Hale, Connie L. and Susan K. Green. 2009. “Six Key Principles for Music Assessment.” Music Educators Journal 95:27-31.

Latimer, Millard E. Jr. 2007. “Adjudicator Reliability: A Comparison of the use of State Festival Choir and Global Score Audition Forms.” Contributions to Music Education 34:67-82.

Mastrorilli, Tara M., M. Phil, Susanne Harnett, and Jing Zhu. 2014. “An Experimental Study of the Arts Achieve Project: Impacting Student Success in the Arts.” Paper presentation at 
the annual meeting for the American Educational Research Association, Philadelphia, PA, April 3-7.

McPherson, Gary E. and James M. Renwick. 2011. "Self-regulation and Mastery of Musical Skills.” In Handbook of Self-regulation of Learning and Performance, edited by Barry J. Zimmerman and Dale H. Schunk, 234-248. New York: Routledge.

Parkes, Kelly. 2010. "Performance Assessment: Lessons from Performers.” International Journal of Teacher and Learning in Higher Education 22:98-106.

Perkins, David. 2003. King Arthur's Round Table: How Collaborative Conversations Create Smart Organizations. Hoboken, NJ: John Wiley \& Sons.

Sadler, David R. 1989. "Formative Assessment and the Design of Instructional Systems.” Instructional Science 18:119-144.

Scott, Sheila. 2012. "Rethinking the Roles of Assessment in Music Education.” Music Educators Journal 98:31-35.

Sinsabaugh, Katherine. 2015. "Idea Bank: Mirror, Mirror on the Wall . . . How Do I Help My Students Become Better Musicians?” Music Educators Journal 101:19-21.

Wesolowski, Brian. 2014. “Documenting Student Learning in Music Performance: A Framework.” Music Educators Journal 101:77-85.

Zessoules, Rieneke and Howard Gardner. 1991. "Authentic Assessment: Beyond the Buzzword and into the Classroom.” In Expanding Student Assessment, edited by Vito Perrone. Alexandria, VA: ASCD. 
Figure 1. Ms. Michelle Turner's Keyboard Checklist

Title:

\begin{tabular}{|l|l|l|l|l|}
\hline PITCH & BEAT & RHYTHM & \\
\hline $\begin{array}{l}\text { I kept my } \\
\text { hands in } \\
\text { place. }\end{array}$ & $\begin{array}{l}\text { I felt the } \\
\text { "tick-tock" } \\
\text { inside while I } \\
\text { played. }\end{array}$ & $\begin{array}{l}\text { I held each } \\
\text { (whole, half, } \\
\text { quarter, eighth, } \\
\text { etc.) note in the } \\
\text { rhythm for the } \\
\text { correct number } \\
\text { of beats. }\end{array}$ & \\
\hline $\begin{array}{l}\text { I used the } \\
\text { correct } \\
\text { fingers. }\end{array}$ & $\begin{array}{l}\text { The "tick- } \\
\text { tock" stayed } \\
\text { the same } \\
\text { tempo to the } \\
\text { end. }\end{array}$ & $\begin{array}{l}\text { any (whole, } \\
\text { half, quarter, } \\
\text { eighth, etc.) } \\
\text { notes in each } \\
\text { rhythm. }\end{array}$ & \\
\hline $\begin{array}{l}\text { I used the } \\
\text { correct hand. }\end{array}$ & $\begin{array}{l}\text { My "tick } \\
\text { tock" was } \\
\text { steady, did } \\
\text { not stutter, } \\
\text { and was not } \\
\text { hesitant. } \\
\text { eighth, etc.) } \\
\text { notes fit inside } \\
\text { the beat. }\end{array}$ & \\
\hline $\begin{array}{l}\text { I } \\
\text { remembered } \\
\text { to switch } \\
\text { hands. }\end{array}$ & $\begin{array}{l}\text { I kept the } \\
\text { flow. }\end{array}$ & $\begin{array}{l}\text { I kept the rests } \\
\text { silent. }\end{array}$ & \\
\hline
\end{tabular}

Figure 2. Ms. Michelle Turner's Keyboard Reflection

KEYBOARD REFLECTION for Page

The area that has the most problems is

Rhythm

Beat

Pitch

because 
Figure 3. Ms. Meghan Phadke’s Recorder Practice Checklist

\section{RECORDER PRACTICE CHECKLIST}

\section{NAME:}

During my practice time today I:

1. Looked at the whole song to find out:

o If I know the song

o How many measures/systems it is long

0 If there are any special markings (like a repeat sign)

0 If there are any repeated patterns or measures

0 If it will be easy or tricky

2. Clapped the rhythm

3. Used G clef and hand staff to identify the note names

4. Clapped the rhythm while singing each pitch (the letter name or with solfège)

5. Used my fingering chart to find how to play each note

6. Fingered the notes in the air while singing each pitch (the letter name or with solfège) solfège)

7. Fingered the notes on the recorder while singing each pitch (the letter name or with

8. Practiced playing the whole song on the recorder 7 times without mistakes or stopping) $\quad 1 \quad 2 \quad 3 \quad 4 \quad 5 \quad 6 \quad 7$

9. Completed my self-assessment, made needed revisions, and got 6 "Always" checks

10. Completed my peer assessment with a partner, made needed revisions

11. READY FOR MY PLAYING TEST! 
Figure 4. Ms. Meghan Phadke's Recorder Self- and Peer Assessment Checklists

RECORDER SELF-ASSESSMENT

Name:

Song Title:

\begin{tabular}{|l|l|l|l|}
\hline Skill & Always & $\begin{array}{l}\text { Still } \\
\text { working }\end{array}$ & How do I fix it? \\
\hline $\begin{array}{l}\text { Plays with a gentle } \\
\text { beautiful tone (no } \\
\text { squeaks!) }\end{array}$ & & & Check your breath and posture! \\
\hline Plays correct notes & & & $\begin{array}{l}\text { Use your G clef and hand staff to } \\
\text { check each note! }\end{array}$ \\
\hline $\begin{array}{l}\text { Uses correct } \\
\text { fingering }\end{array}$ & & Check fingering chart! \\
\hline $\begin{array}{l}\text { Covers holes } \\
\text { completely with } \\
\text { finger pads }\end{array}$ & & Check your fingertips for circles! \\
\hline $\begin{array}{l}\text { Plays rhythms } \\
\text { correctly }\end{array}$ & & & $\begin{array}{l}\text { Clap the rhythm and see if it } \\
\text { matches! }\end{array}$ \\
\hline $\begin{array}{l}\text { Plays whole song on } \\
\text { the first try }\end{array}$ & & SLOW DOWN \\
\hline
\end{tabular}

\section{RECORDER PEER ASSESSMENT}

Student completing this form:

Student playing the recorder:

Song Title:

\begin{tabular}{|l|l|l|l|}
\hline Skill & Always & $\begin{array}{l}\text { Still } \\
\text { working }\end{array}$ & How can your partner fix it? \\
\hline $\begin{array}{l}\text { Plays with a gentle } \\
\text { beautiful tone (no } \\
\text { squeaks!) }\end{array}$ & & & \\
\hline Plays correct notes & & & \\
\hline $\begin{array}{l}\text { Uses correct } \\
\text { fingering }\end{array}$ & & & \\
\hline $\begin{array}{l}\text { Covers holes } \\
\text { completely with } \\
\text { finger pads }\end{array}$ & & & \\
\hline $\begin{array}{l}\text { Plays rhythms } \\
\text { correctly }\end{array}$ & & & \\
\hline $\begin{array}{l}\text { Plays whole song on } \\
\text { the first try }\end{array}$ & & & \\
\hline
\end{tabular}


Figure 5. Ms. Maria Comba’s Melody Checklist

\section{Contours!!!}

I can draw a contour using straight, bumpy, squiggly, or sharp lines.

I can echo back a contour.

I can sing the contour that I composed.

I can sing the contour that my partner composed.

I can follow a contour while someone else is singing.

I can sing a contour that stays on the same pitch. (my pitch doesn't webble and wabble) I can sing a contour that moves in different directions.

I need to work on

Date:

\section{Listening for Movement!!!}

I understand the definitions to the vocabulary words/terms. (pitch, ascending/descending, higher/lower pitch, step, skip, listening for movement, solfège, contour, melody, notate)

I can give examples of them AND identify them.

I can sing notes moving in different directions.

I can echo back the melody.

I need to work on

Date:

\section{Things to remember:}


Figure 6. Ms. Maria Comba's Melody Rubric

\begin{tabular}{|c|c|c|c|c|}
\hline & I've GOT it! & $\begin{array}{l}\text { AHH-HAA... } \\
\text { I'm almost } \\
\text { there! }\end{array}$ & $\begin{array}{l}\text { I'm getting } \\
\text { better! }\end{array}$ & $\begin{array}{l}\text { I need some } \\
\text { help please. }\end{array}$ \\
\hline $\begin{array}{l}\text { Drawing the } \\
\text { Contour }\end{array}$ & $\begin{array}{l}\text { I got it! Not only } \\
\text { can I draw the } \\
\text { contour, but I } \\
\text { can add details } \\
\text { so it starts to } \\
\text { look like a } \\
\text { melody on the } \\
\text { staff. }\end{array}$ & $\begin{array}{l}\text { Ahh- Ha! I CAN } \\
\text { draw the contour } \\
\text { correctly. Now } \\
\text { I'm working on } \\
\text { notating some } \\
\text { details so it can } \\
\text { start to look like } \\
\text { a melody line on } \\
\text { a staff. }\end{array}$ & $\begin{array}{l}\text { I can draw the } \\
\text { contour when it } \\
\text { moves in one } \\
\text { direction only. } \\
\text { Now I'm } \\
\frac{\text { working on }}{\text { "listening for }} \\
\text { movement" in } \\
\text { contours that } \\
\text { move in } \\
\text { different } \\
\text { directions. }\end{array}$ & $\begin{array}{l}\text { Now I'm } \\
\underline{\text { working on }} \\
\text { “listening for } \\
\text { movement." I'm } \\
\text { always asking } \\
\text { myself if the } \\
\text { music sounds } \\
\text { like it's moving } \\
\text { up the stairs or } \\
\text { down the stairs. }\end{array}$ \\
\hline $\begin{array}{l}\text { Notating the } \\
\text { Melody on the } \\
\text { Staff }\end{array}$ & $\begin{array}{l}\text { I can notate the } \\
\text { melody when } \\
\text { given the } \\
\text { starting pitch. I } \\
\text { used "listening } \\
\text { for movement," } \\
\text { melodic motion } \\
\text { (ascending, } \\
\text { descending, step, } \\
\text { skip), and } \\
\text { solfège to help } \\
\text { me. }\end{array}$ & $\begin{array}{l}\text { I can use the } \\
\text { starting pitch } \\
\text { and melodic } \\
\text { motion to help } \\
\text { me figure out the } \\
\text { movements and } \\
\text { relationships of } \\
\text { pitches in the } \\
\text { melody. Now } \\
\text { I'm working on } \\
\text { writing notes } \\
\text { closer to their } \\
\text { actual pitch. } \\
\text { Using melodic } \\
\text { motion and } \\
\text { solfège will help. }\end{array}$ & $\begin{array}{l}\text { I can notate the } \\
\text { direction of the } \\
\text { contour by using } \\
\text { melodic motion } \\
\text { but cannot place } \\
\text { them on the staff } \\
\text { as of yet. Now } \\
\text { I'm working on } \\
\text { using the starting } \\
\text { pitch to help me } \\
\text { place notes on } \\
\text { the staff. }\end{array}$ & $\begin{array}{l}\text { Now I am } \\
\text { working on } \\
\text { "listening for } \\
\text { movement" and } \\
\text { matching it up } \\
\text { with melodic } \\
\text { motion. I will } \\
\text { always follow } \\
\text { picture cues with } \\
\text { my finger to see } \\
\text { if they match. }\end{array}$ \\
\hline $\begin{array}{l}\text { Singing the } \\
\text { Melody }\end{array}$ & $\begin{array}{l}\text { I can sing the } \\
\text { melody line } \\
\text { when given the } \\
\text { starting pitch. I } \\
\text { used melodic } \\
\text { motion and } \\
\text { solfège to help } \\
\text { me. }\end{array}$ & $\begin{array}{l}\text { I can sing the } \\
\text { melody line } \\
\text { moving in the } \\
\text { right direction } \\
\text { but the pitches } \\
\text { are not accurate. } \\
\underline{\text { Now I'm }} \\
\frac{\text { working on }}{\text { being more }} \\
\text { accurate with } \\
\text { each individual } \\
\text { pitch. }\end{array}$ & $\begin{array}{l}\text { I can sing the } \\
\text { contour but } \\
\text { cannot match } \\
\text { individual notes. } \\
\text { Now I'm } \\
\underline{\text { working on }} \\
\text { using solfège to } \\
\text { help me sing the } \\
\text { correct pitch. }\end{array}$ & $\begin{array}{l}\text { Now I'm } \\
\text { working on } \\
\text { making sure that } \\
\text { my voice is } \\
\text { going in the right } \\
\text { direction. I'm } \\
\text { listening, tracing } \\
\text { contours and } \\
\text { echoing. }\end{array}$ \\
\hline
\end{tabular}

